\title{
Application of a FBG-Based Instrumented Rock Bolt in a TBM- Excavated Coal Mine Roadway
}

\author{
Bin Tang $\mathbb{D}^{1,2,3}$ Hua Cheng $\mathbb{D}^{1},{ }^{1}$ Yongzhi Tang, ${ }^{4}$ Zhishu Yao, ${ }^{1}$ Chuanxin Rong, \\ Weipei Xue iD, ${ }^{1,3,5}$ and Jian $\operatorname{Lin}^{1}$ \\ ${ }^{1}$ School of Civil Engineering and Architecture, Anhui University of Science and Technology, 168 Taifeng St, Huainan 232001, China \\ ${ }^{2}$ Postdoctoral Research Station, Huainan Mining Industry (Group) Co. Ltd., No. 6 Building, Zhihui Valley, Huainan 232001, China \\ ${ }^{3}$ Research Center of Mine Underground Engineering of Ministry of Education, Anhui University of Science and Technology, \\ 168 Taifeng St, Huainan 232001, China \\ ${ }^{4}$ Huainan Mining Industry (Group) Co. Ltd., 1 Dongshan Middle Rd, Huainan 232001, China \\ ${ }^{5}$ Postdoctoral Research Station of Safety Science and Engineering, Anhui University of Science and Technology, \\ Huainan 232001, China
}

Correspondence should be addressed to Bin Tang; 2016039@aust.edu.cn and Hua Cheng; hcheng@aust.edu.cn

Received 3 May 2018; Revised 17 July 2018; Accepted 30 July 2018; Published 17 September 2018

Academic Editor: Carlos Ruiz

Copyright @ 2018 Bin Tang et al. This is an open access article distributed under the Creative Commons Attribution License, which permits unrestricted use, distribution, and reproduction in any medium, provided the original work is properly cited.

\begin{abstract}
Rock bolts have been widely applied with roadway excavation in underground coal mines to prevent roadway collapse and improve the stability of roadway surrounding rocks. Overloading and failures of rock bolts could result in accidents or casualties in coal mine roadways. Consequently, monitoring axial forces and work conditions of rock bolts plays an increasingly important role in ensuring safe operations of underground coal mines. Conventional mechanical or electronic rock bolt monitoring systems are typically affected by electromagnetic interference, corrosive groundwater, and dusty circumstance in underground working sites. This work proposed a FBG-based instrumented rock bolt. Quasi-distributed FBG sensors were installed on a slotted rock bolt and encapsulated by epoxy resin that was used to fix FBG sensors on the rock bolt and protect FBG sensors from damage. The FBG sensors were calibrated before the in situ application. Monitoring results indicated that the axial forces of rock bolts installed on the roof of the roadway were higher than that of others, and the maximum axial forces of each rock bolt were typically detected near the middle portion of rock bolts. A real-time and accurate rock bolt monitoring system was established by integrating instrumented rock bolts to the existing monitoring system of the coal mine.
\end{abstract}

\section{Introduction}

As the coal resources within shallow grounds are depleting and coal mining operations are moving to deeper grounds, approximately $60 \%$ of the coal mining works are currently conducted with a mining depth of over $800 \mathrm{~m}$ in China [1]. The impacts of high ground stress and weak strata are encountered within the mining operation works in deeply buried coal mines $[2,3]$. Roadways are prone to collapse in these adverse geological conditions, and the roadway collapse contributes to $43 \%$ fatalities of miners in underground coal mines in China $[4,5]$. Considering safety issues, the roadway support is playing an increasingly important role in coal mining operations [6]. The rock bolt is one of the most popular supporting materials in underground coal mining due to its installation flexibility and low price [7]. The failure and malfunction of rock bolts generally result in the large deformations or even collapses of roadways. Therefore, the monitoring of rock bolt performance and surrounding rock stability has become a critical issue in the area of roadway support.

It has been widely recognized by researchers that the axial force is a critical parameter for evaluating rock bolt performance. Conventional axial force monitoring operations were typically conducted by using load cells. The load cells were applied to measure the axial force of rock bolts, thereby 
verifying that the rock bolts are functioning adequately and not subjected to excessive load. Load cells are manufactured with a center hole to accommodate rock bolts, and they are commonly installed on the rear portion of rock bolts. Several types of load cells were developed based on mechanical or electronic sensing technologies such as the mechanical load cell, hydraulic pressure load cell, vibrating wire load cell, and electrical resistance load cell. Various conventional rock bolt monitoring systems had been widely applied in recent decades. However, some problems were encountered during the in situ applications, including (i) corrosive groundwater and dusty circumstance cause failure of mechanical and electronic sensors, (ii) electronic sensors are susceptible to electromagnetic interference, (iii) monitoring of data collection relies on laborious manual operations, and (iv) hard implementation of real-time and remote monitoring [8]. The conventional mechanical or electronic sensing technologies are not capable of fulfilling the demands of application in underground coal mines.

The fiber Bragg grating (FBG) sensor is a promising optical fiber sensing technology emerged in the recent two decades, which has advantages in contrast with conventional mechanical or electronic sensing technologies such as safety, corrosion proof, high accuracy, immunity to electromagnetic interference, long duration, and convenience on conducting online monitoring [9-11]. Taking advantages of optical fiber sensing technologies, several newly developed rock bolt load monitoring devices had been proposed. Ho et al. [12] installed FBG sensors on the plate of a rock bolt for measuring axial force of the rock bolt. Liang and Fang [13] developed a novel rock bolt load cell by installing FBG sensors on a conventional hydraulic pressure load cell. Zhao et al. [14] developed a monitoring cylinder fitted with FBG sensors for measuring axial force of rock bolts. These devices increased monitoring accuracy of rock bolt load monitoring. Because sensors are installed on the end portion of the rock bolt, the force distribution on the middle and top portions of the rock bolt is not well represented.

In order to measure strain and stress distribution on various parts of the rock bolt, an instrumented rock bolt with optical fiber sensors fitted along the rock bolt was proposed by researchers. Nellen and Broennimann [15] presented a glass fiber reinforced polymer (GFRP) instrumented rock bolt with embedded fiber Bragg grating sensors. Huang et al. [16] proposed a fiber reinforced plastic (FRP) rock bolt with built-in optical fiber sensors. With the optical fiber sensors installed on the rebar or rod of rock bolts, the rock bolts can be applied to obtain strain distributions along the rock bolt body. However, above-mentioned instrumented rock bolts cannot be used in underground coal mines. Specifically, in coal mine roadway support applications, the steel rock bolt is preferred due to the inadequate mechanical properties of FRP rock bolts. Current instrumented rock bolts are made up of plastic or polymer materials, and the optical fiber sensors are capable of being embedded within the FRP rock bolts during the manufacture stage $[17,18]$. Whereas the steel rock bolt subjects to high temperature and stress during the manufacture stage, which results in difficulties on optical fiber installation in steel rock bolts.
This paper proposed a steel FBG-based instrumented rock bolt for monitoring of axial force of rock bolts. The FBG sensors were embedded within a slotted rock bolt and encapsulated by epoxy resin. After calibration of FBG sensors, the FBG-based instrumented rock bolts were installed in surrounding rocks of the roadway. The instrumented rock bolts provided real-time and accurate monitoring data of axial force of the rock bolt. Therefore, an early warning can be obtained before rock bolt failure by integrating the instrumented rock bolt into a monitoring network of the coal mine.

\section{Structure and Principle of the FBG-Based Instrumented Rock Bolt}

2.1. Structure of the FBG-Based Instrumented Rock Bolt. The FBG-based instrumented rock bolt was made of a steel tendon with a threaded outer surface. In this study, the diameter and length of the rock bolt are $22 \mathrm{~mm}$ and $2500 \mathrm{~mm}$, respectively. The rock bolt was slotted with $3 \mathrm{~mm}$ by $3 \mathrm{~mm}$ diametrically opposing grooves along the entire length of the rock bolt. The FBG optical sensors were held within the grooves by epoxy resin, and therefore, the sensors were coupled to the surface of the rock bolt. The epoxy resin completely encapsulates the fiber within the grooves and therefore protects the sensor throughout installation and handling of the rock bolt. The configuration of the FBG-based instrumented rock bolt can be seen in Figure 1.

2.2. Basic Principle of FBG. A fiber Bragg grating (FBG) is a wavelength-dependent filter/reflector constructing periodic refractive index structures within the core of a single-mode optical fiber by laterally exposing the core of a single-mode optical fiber to a periodic pattern of intense ultraviolet light [19-21]. This makes a FBG reflects particular wavelengths (known as Bragg wavelengths) of light and transmits all others. The Bragg wavelength is expressed as

$$
\lambda_{B}=2 n_{\mathrm{eff}} \Lambda,
$$

where $\lambda_{B}$ represents the Bragg wavelength, $n_{\text {eff }}$ indicates the effective index of refraction, and $\Lambda$ is the grating period.

Differentiating (1) gets

$$
\frac{\mathrm{d} \lambda_{B}}{\lambda_{B}}=\frac{d n_{\mathrm{eff}}}{n_{\mathrm{eff}}}+\frac{d \Lambda}{\Lambda} .
$$

The longitudinal strain on the FBG can be calculated as

$$
\varepsilon=\frac{d \Lambda}{\Lambda}
$$

The effective elasto-optical coefficient of the optical fiber can be described as

$$
p_{e}=-\frac{d n_{\mathrm{eff}}}{n_{\mathrm{eff}}}=-\frac{n_{\mathrm{eff}}^{2}}{2}\left[p_{12}-\mu\left(p_{11}+p_{12}\right)\right] \varepsilon,
$$




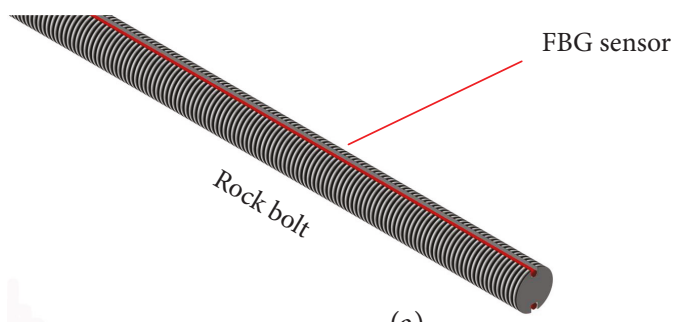

(a)
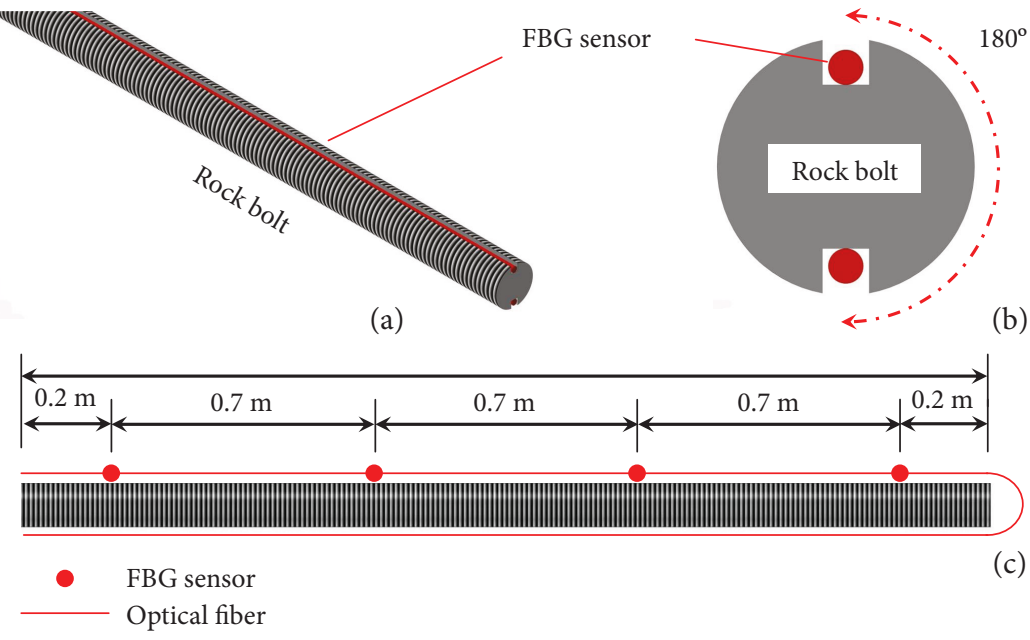

FIGURE 1: Configuration of the FBG-based instrumented rock bolt: (a) sketch of the FBG-based instrumented rock bolt; (b) cross section; (c) plan view.

where $p_{e}$ is the effective elasto-optical coefficient, $p_{i j}$ are the silica photo-elastic tensor components, and $\mu$ is Poisson's ratio.

Based on (2), (3), and (4), the relationship between the Bragg wavelength shift and applied strain can be described as

$$
\frac{\Delta \lambda_{B}}{\lambda_{B}}=\left(1-p_{e}\right) \varepsilon
$$

where $\Delta \lambda_{B}$ is the Bragg wavelength shift.

The Bragg wavelength is also affected by temperature. Differentiating both sides of (1) with respect to temperature $T$, the temperature-induced Bragg wavelength shift can be compensated by

$$
\frac{\mathrm{d} \lambda_{B}}{\lambda_{B}}=\left(\frac{1}{n_{\text {eff }}} \frac{d n_{\text {eff }}}{d T}+\frac{1}{\Lambda} \frac{d \Lambda}{\Lambda}\right) d T .
$$

Setting $\xi=\left(1 / n_{\mathrm{eff}}\right)\left(d n_{\mathrm{eff}} / d T\right)$ and $\alpha=(1 / \Lambda)(d \Lambda / \Lambda)$, then (6) can be rewritten as

$$
\frac{\Delta \lambda_{B}}{\lambda_{B}}=(\alpha+\xi) \Delta T,
$$

where $\Delta T$ is the temperature change, $\alpha$ is the coefficient of thermal expansion, and $\xi$ is the thermo-optic coefficient.

Considering coupling effect of strain and temperature on the Bragg wavelength shift, the effective Bragg wavelength shift can be obtained by combining (5) and (7):

$$
\frac{\Delta \lambda_{B}}{\lambda_{B}}=(\alpha+\xi) \Delta T+\left(1-p_{e}\right) \varepsilon
$$

Equation (8) can also be expressed as

$$
\frac{\Delta \lambda_{B}}{\lambda_{B}}=K_{T} \Delta T+K_{\varepsilon} \varepsilon,
$$

where $K_{T}$ and $K_{\varepsilon}$ are coefficients of wavelength sensitivity to temperature and strain, respectively.

The axial force of the rock bolt can be expressed as

$$
F=\sigma A=E \varepsilon A
$$

Inserting (9) into (10), the axial force of the rock bolt can be expressed as

$$
F=E A \frac{\Delta \lambda_{B} / \lambda_{B}-K_{T} \Delta T}{K_{\varepsilon}} .
$$

It can be seen that the axial force of the rock bolt can be obtained by measuring the Bragg wavelength shift of FBG optical sensors. When broadband light passes through the Bragg gratings, only particular narrowband light wavelengths (known as Bragg wavelengths) are reflected and light of other wavelengths without significant attenuation is transmitted. The Bragg wavelengths of optical fibers are influenced by strain and temperature; thus, the strain and temperature values can be obtained by measuring Bragg wavelength shifts. The working principle of FBG sensors is depicted in Figure 2.

\section{Performance Experiments of the Instrumented Rock Bolt}

Before implementing the FBG-based instrumented rock bolt in underground working sites, the mechanical property of the instrumented rock bolt was tested. Moreover, the calibration was conducted in laboratory to characterize mechanical behaviors of instrumented rock bolts.

The tensile tests of normal and slotted instrumented rock bolts were conducted. Therefore, the yield strength and limited strength of both normal rock bolts and slotted rock bolts were recorded and analyzed. The test results indicate that the yield strength of the slotted rock bolt is lower than that of the normal rock bolt due to the reduction on the cross section area of slotted rock bolts. The average yield strengths of normal rock bolts and slotted rock bolts are $127.28 \mathrm{kN}$ and 


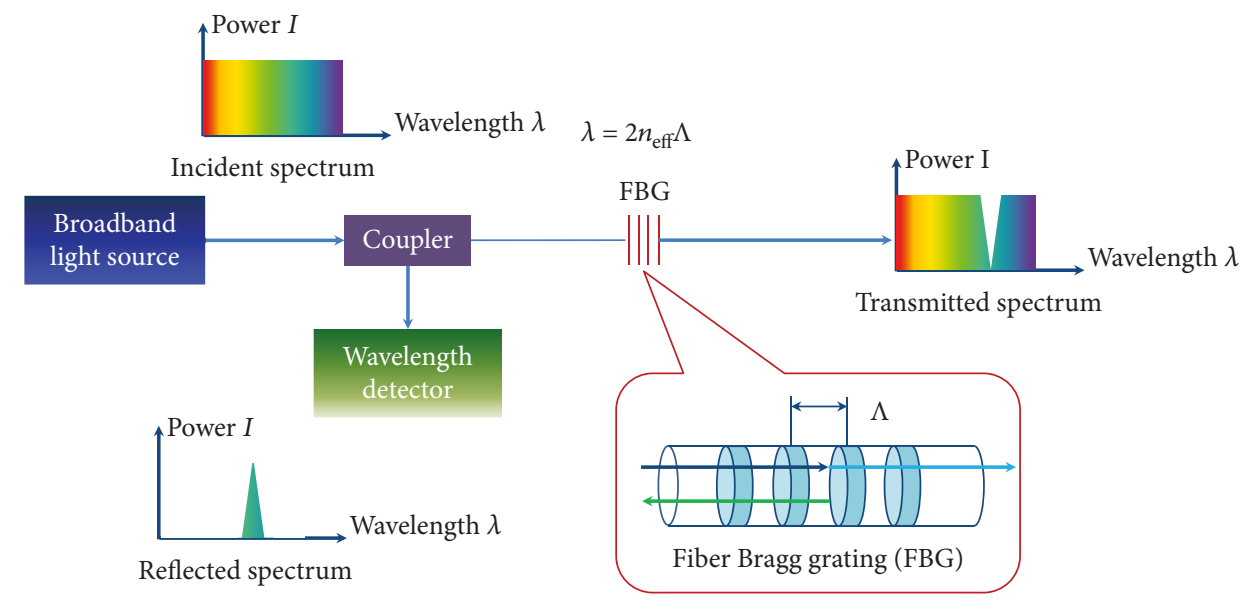

Figure 2: Monitoring principle of FBG sensors.

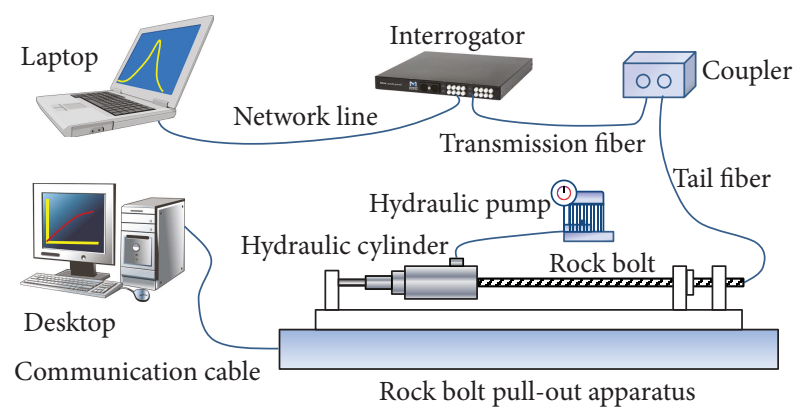

Figure 3: Rock bolt pull-out test apparatus.

$121.32 \mathrm{kN}$. It can be seen from test results that the slotting rock bolt reduced yield strength of the rock bolt by $4.68 \%$. Nevertheless, the strength of the slotted rock bolt still fulfills the requirements of the coal mine safety regulation of China $(100 \mathrm{kN})[22]$.

The calibration experiments of instrumented rock bolts were conducted by a rock bolt pull-out test apparatus and a temperature-controlled tank. Figure 3 shows the schematic of the pull-out test apparatus which is capable of applying axial force on the rock bolt with the range of $0-100 \mathrm{kN}$. Then, the wavelength shift under various axial forces can be recorded by a FBG interrogator. The air temperature was $26.5^{\circ} \mathrm{C}$ when the pull-out test was implemented.

Temperature calibration was implemented by a temperature-controlled tank which was used to provide a constant temperature circumstance for the FBG temperature sensor. The optical fibers were set into the temperaturecontrolled tank, and then water was heated. During the temperature calibration operations, there were no extra forces applied on optical fibers and the strain values of optical fibers are all zero. Therefore, the changes of temperature and wavelength shift during the whole heating process were recorded, and the linear relationship between temperature and wavelength shift was learned.

The axial force applied on the instrumented rock bolt and corresponding wavelength shift are shown in Table 1. Based on the experiment results, data fitting was carried out and
TABLE 1: Results of rock bolt pull-out experiment.

\begin{tabular}{lccccc}
\hline \multirow{2}{*}{ Axial force (kN) } & \multicolumn{5}{c}{ Wavelength shift (nm) } \\
& FBG 1 & FBG 2 & FBG 3 & FBG 4 & Average \\
\hline 10 & 0.0596 & 0.0565 & 0.0524 & 0.0548 & 0.0558 \\
20 & 0.1595 & 0.1552 & 0.1564 & 0.1588 & 0.1575 \\
30 & 0.2593 & 0.2588 & 0.2543 & 0.2598 & 0.2581 \\
40 & 0.3594 & 0.3561 & 0.3518 & 0.3425 & 0.3525 \\
50 & 0.4592 & 0.4593 & 0.4577 & 0.4618 & 0.4595 \\
60 & 0.5589 & 0.5551 & 0.5615 & 0.5588 & 0.5586 \\
70 & 0.6629 & 0.6632 & 0.6699 & 0.6675 & 0.6659 \\
80 & 0.7623 & 0.7685 & 0.7646 & 0.7594 & 0.7637 \\
90 & 0.8622 & 0.8665 & 0.8594 & 0.8749 & 0.8658 \\
100 & 0.9632 & 0.9649 & 0.9654 & 0.9656 & 0.9648 \\
\hline
\end{tabular}

the linear relationship between axial force and wavelength shift was obtained. The laboratory calibration relationship between axial force and wavelength shift is shown in Figure 4(a), and the experiment results of temperature calibration and linear relationship between temperature and wavelength shift are illustrated in Figure 4(b). Consequently, the coefficients of wavelength sensitivity to temperature and strain can be obtained by means of calibration and data fitting. The value of $K_{\varepsilon}$ and $K_{T}$ are $0.01013 \mathrm{~nm} / \mathrm{kN}$ and $0.00699 \mathrm{~nm} /{ }^{\circ} \mathrm{C}$, respectively.

Theoretically, the effective elasto-optical coefficient, coefficient of thermal expansion, and thermo-optic coefficient of all silica-based FBGs should be of the same value. Nevertheless, the difference between rock bolts generated during manufacturing and FBG encapsulation works resulted in various coefficients of wavelength sensitivity to temperature and strain $\left(K_{T}\right.$ and $\left.K_{\varepsilon}\right)$. Therefore, each instrumented rock bolt was calibrated before they were applied in the underground working site. The calibration results are shown in Table 2.

\section{Field Application and Monitoring Results}

4.1. Description of the Monitoring Site. The monitoring site is located at the overlying coalbed methane (CBM) drainage 


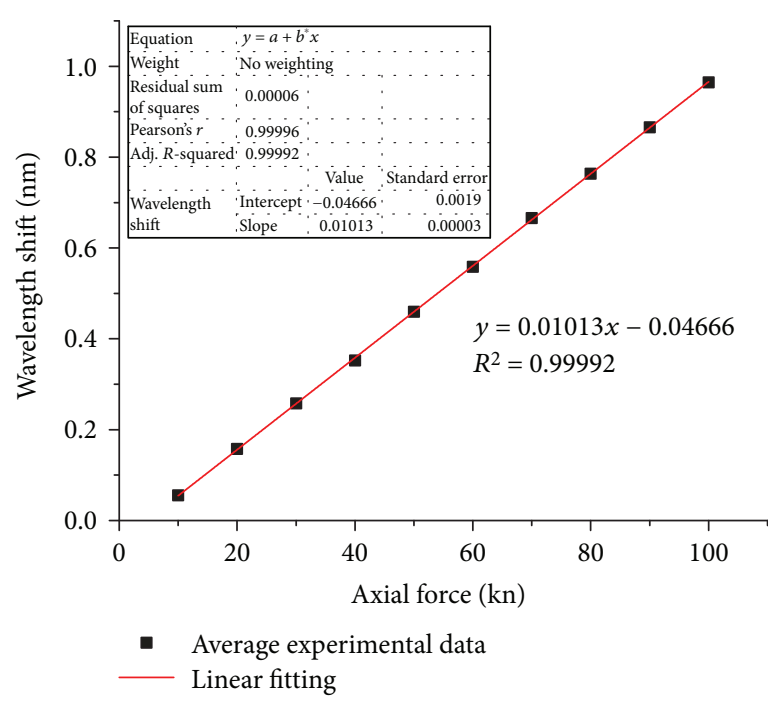

(a)

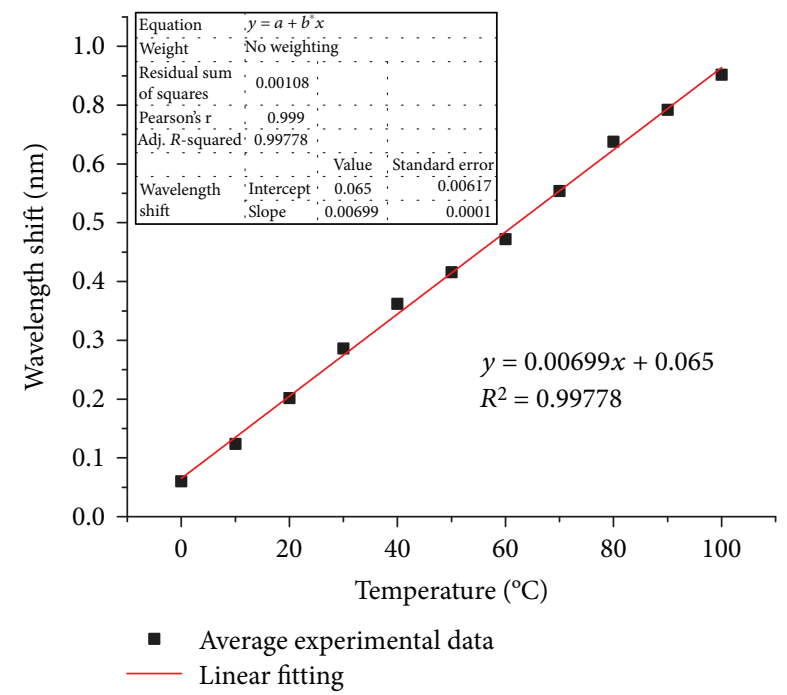

(b)

Figure 4: Experiment results in laboratory calibration: (a) axial force of the rock bolt versus wavelength shift; (b) temperature versus wavelength shift.

TABLE 2: Results of rock bolt pull-out experiment.

\begin{tabular}{|c|c|c|c|c|c|}
\hline & Number 1 rock bolt & Number 2 rock bolt & Number 3 rock bolt & Number 4 rock bolt & Average \\
\hline$K_{\varepsilon}(\mathrm{nm} / \mathrm{kN})$ & 0.01013 & 0.01015 & 0.00971 & 0.00998 & 0.00999 \\
\hline$K_{T}\left(\mathrm{~nm} /{ }^{\circ} \mathrm{C}\right)$ & 0.00699 & 0.00697 & 0.00652 & 0.00683 & 0.00683 \\
\hline
\end{tabular}

roadway of the 1413A longwall panel of Zhangji Coal Mine, Anhui Province, China. The roadway has a length of $1598 \mathrm{~m}$, a diameter of $4.5 \mathrm{~m}$, and a buried depth of $505 \mathrm{~m}$. The roadway was excavated by a tunnel boring machine (TBM). The location of Zhangji Coal Mine and the geological setting of the CBM drainage roadway are illustrated in Figure 5.

The CBM drainage roadway is situated in coal-bearing strata that consist of fine sandstone, medium sandstone, argillaceous sandstone, and a number 1 coal seam. The number 1 coal seam is $6.5 \mathrm{~m}$ in thickness with a dip angle of $2-3^{\circ}$ and situated $25-30 \mathrm{~m}$ beneath the CBM drainage roadway.

The ground stress data had been obtained by borehole stress relief measurements. The measurement results suggested that the ground stress is controlled by tectonic stress. The orientation of the maximum horizontal stress is $116.3^{\circ}$, and the magnitude of vertical stress, the minimum horizontal stress, and the maximum horizontal stress are $14.5 \mathrm{MPa}$, 13.4 $\mathrm{MPa}$, and $37.4 \mathrm{MPa}$, respectively. This direction of maximum horizontal stress is in agreement with the local geological setting.

The roadway was supported by rock bolts $(22 \mathrm{~mm}$ in diameter and $2.5 \mathrm{~m}$ in length) and steel meshes. The rock bolts were installed on the roof of the roadway with an interval of $1 \mathrm{~m} \times 1 \mathrm{~m}$ to ensure the stability of roadway surrounding rocks and protect the personnel from roof collapse. Typically, there were six rock bolts installed in each row.
The coal mine roadways are conventionally excavated by drilling and blasting, while the TBMs are newly introduced in coal mine roadway excavation projects [24-27]. The roadway surrounding rocks show various stress distribution characters and convergence behaviors under different excavation methods. Consequently, the force distribution characters of rock bolts in TBM-excavated roadways need to be studied. The monitoring data of axial force of rock bolts are able to provide a reference for surrounding rock control, safety evaluation, and support design of TBM-excavated roadways.

4.2. Layout of the Monitoring System. The monitoring station is situated $350 \mathrm{~m}$ away from the portal of the roadway. Four instrumented rock bolts were installed on the roof of the roadway with various inclined angles. The orientations of number 1 , number 2 , number 3 , and number 4 instrumented rock bolts are $38.2^{\circ}, 71.6^{\circ}, 122.9^{\circ}$, and $158.4^{\circ}$, respectively. Moreover, a FBG temperature sensor was placed within a hollow tube and installed within a borehole that was drilled on the roadway surrounding rock, and this configuration is able to protect the temperature sensor from the damage caused by roadway excavation works. In addition, the temperature sensor installed within surrounding rock was barely affected by the temperature change of ventilation airflow. Consequently, instrumented rock bolts and the temperature sensor were all operated under similar temperate conditions, and the error caused by temperature can be reduced significantly. A NZS-FBG-A04 interrogator with a maximum 


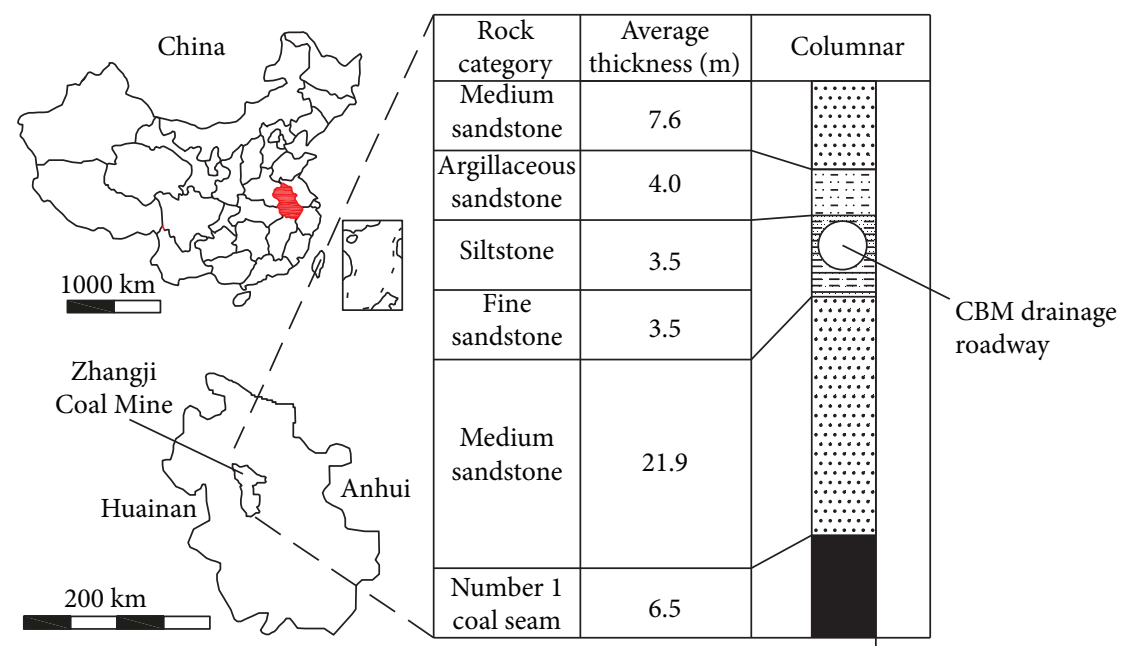

FIGURE 5: Location and strata histogram of the CBM drainage roadway in Zhangji Coal Mine [23].

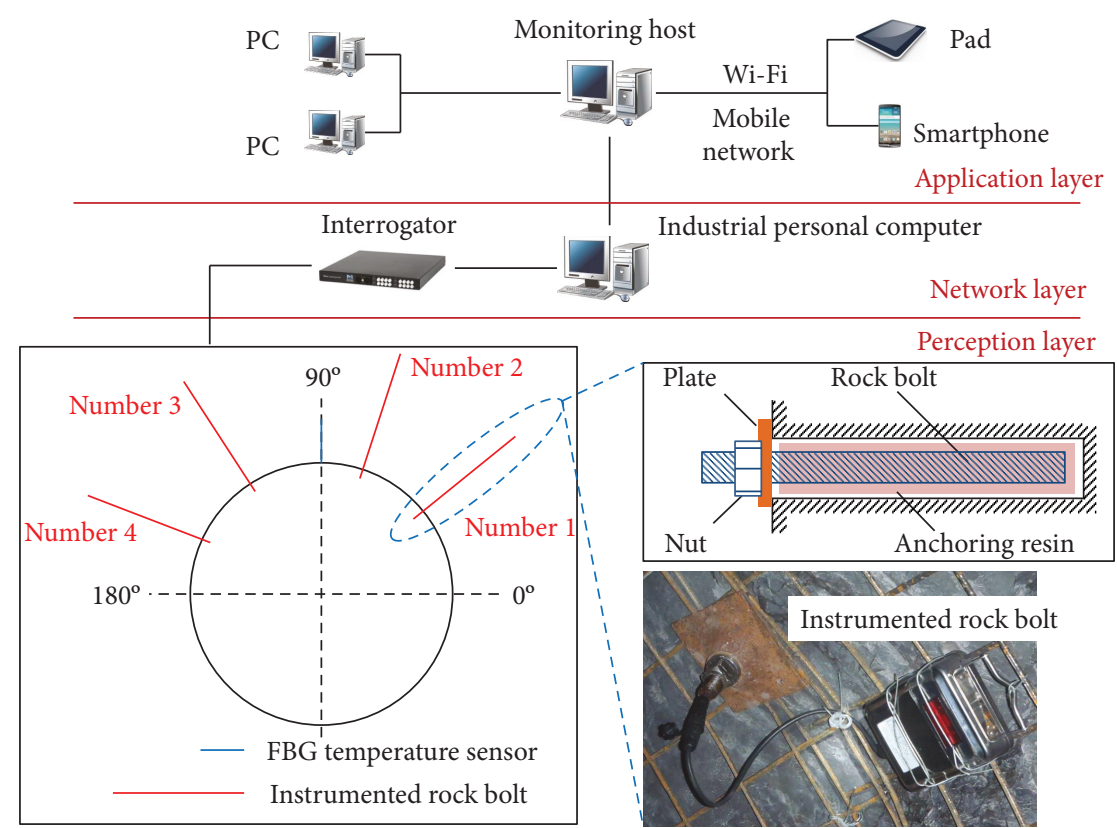

FIGURE 6: Layout of the FBG-based instrumented rock bolt monitoring system.

integration frequency of $100 \mathrm{~Hz}$ was used in monitoring. During the monitoring operations, the system was set to record monitoring data every 30 minutes. The sampling frequency is able to fulfill the requirements of axial forces and structural health monitoring of rock bolts considering the evolution rate of stress and displacement field of roadway surrounding rocks.

The FBG-based instrumented rock bolt monitoring system was established by integrating FBG sensing devices to the communication system of Zhangji Coal Mine. The instrumented rock bolt monitoring system consists of the perception layer, network layer, and application layer, as shown in Figure 6. The perception layer is composed of instrumented rock bolts and FBG temperature sensors. The instrumented rock bolts were used to measure axial forces of rock bolts, and the FBG temperature sensors were implemented to correct the error of measuring data which was caused by temperature variations. Therefore, an integrated sensing framework for axial force monitoring was established. The network layer was designed to process and transmit the data received from the perception layer. It consists of the FBG interrogator, industrial personal computer, and communication substation. The FBG interrogator and computer are capable of collecting and analyzing the data obtained from sensors. Once the axial force of rock bolts exceed allowable value $(100 \mathrm{kN})$, an early warning of overloading and failure of rock bolts can be provided. The application layer consists of a monitoring host and information exchange network. This layer enables remote information sharing, and the monitoring data can be obtained by using various terminal equipment (e.g., personal computer, laptop, smartphone, and pad) via the internet. 


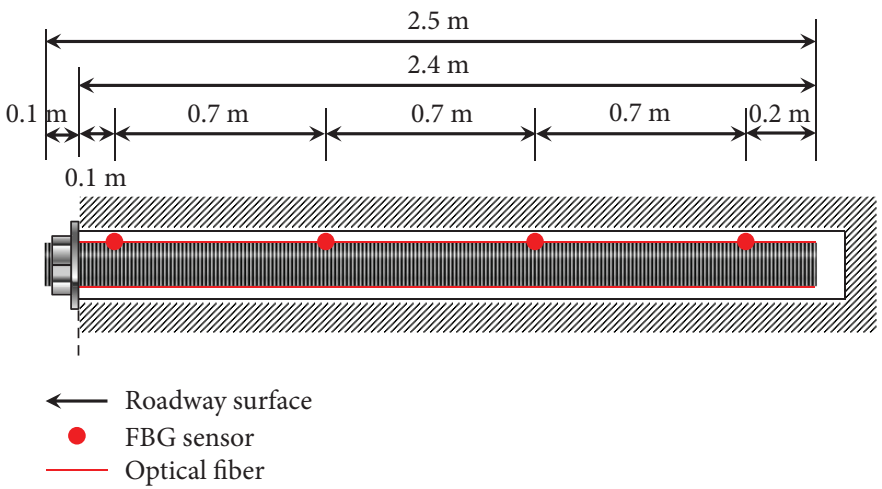

FIGURE 7: Sketch of the instrumented rock bolt installation.

4.3. Instrumented Rock Bolt Installation. The installation procedure of instrumented rock bolts is as follows. (1) Drill a borehole from the roadway perpendicular to the rock surface. (2) Install anchoring resin cartridges within the borehole. (3) Install the rock bolt in the borehole. (4) After anchoring resin curing, install plate and nut on the rear of the rock bolt. (5) Connect data communication optical fibers.

As shown in Figure 7, a $0.1 \mathrm{~m}$ long part of the rock bolt was left out of the borehole for plate and nut installation. The distances between the roadway surface and four FBG sensors are $0.1,0.8,1.5$, and $2.2 \mathrm{~m}$, respectively.

\section{Analysis of Monitoring Results}

The monitoring operations of axial force of rock bolts had been conducted after the roadway was excavated. The axial forces applied on different parts of each instrumented rock bolts were recorded and analyzed. Figure 8 shows the axial force applied to different positions of instrumented rock bolts versus time.

As can be seen from Figure 8, the axial force of four instrumented rock bolts experienced dramatic increase during 10 to 15 days after installation. Then slower increases on axial force of rock bolts were detected and magnitude of axial forces stabilized at various levels since around 40 days after rock bolt installation. The maximum axial force of number 1 rock bolt increased to $33 \mathrm{kN}$ within 10 days, and then it went up to $47 \mathrm{kN}$ on the 20th day. During the last 60 days of monitoring works, the axial force merely increased by $2 \mathrm{kN}$ (up to $49.6 \mathrm{kN}$ ). The maximum axial force of number 2 rock bolt increased rapidly and arrived at $60 \mathrm{kN}$ within 13 days. The maximum axial force finally reached a plateau at $84.8 \mathrm{kN}$ after it underwent two major fluctuations of growth rate. The axial force variation of number 3 rock bolt was similar to that of number 1 rock bolt. Axial force surge took place in the first ten days of monitoring. Then the growth rate of axial forces continued to decrease, and the maximum axial force applied on number 3 rock bolt remained stable at around $78 \mathrm{kN}$. The axial force on number 4 rock bolt increased gradually in the first three days; then the axial force grew substantially, and finally, the maximum axial force levelled off at $31 \mathrm{kN}$.
The temperature of deep grounds is mainly influenced by geothermal heat rather than atmosphere temperature [28]. During the initial period of monitoring, the temperature was about $28^{\circ} \mathrm{C}$ due to heat radiating from TBM and other excavation equipment. After three days, as excavation equipment moved far away from the monitoring site, the temperature was affected slightly by ventilation airflow because the temperature sensor was installed within the surrounding rocks. The measured temperature values fluctuated from 23 to $26^{\circ} \mathrm{C}$.

After roadway excavation, the stress field and displacement field of roadway surrounding rocks were disturbed. Moreover, the fractured zone, plastic zone, elastic zone, and in situ stress zone were formed from the shallow to deep layer of roadway surrounding rocks. The different stress and displacement magnitude distributions in different areas of surrounding rocks resulted in various axial forces applied on different parts of rock bolts. The monitoring results illustrated that the maximum and minimum axial forces of each rock bolt were detected by FBG sensors that were situated $1.5 \mathrm{~m}$ and $0.1 \mathrm{~m}$ away from the roadway surface, respectively. The monitoring data suggested that the middle portion of rock bolts suffered from much larger axial force, and the surrounding rocks in this area experienced the largest deformation. This axial force distribution character cannot be revealed by monitoring devices that were installed on the rear portion of rock bolts.

The axial forces of four instrumented rock bolts were in agreement with orientations and locations of rock bolts. Specifically, the closer a rock bolt to the apex of the roadway roof, the greater axial force applied to the rock bolt. This phenomenon indicates that the displacement on the roadway roof is larger than that on lateral sides of the roadway. The maximum axial forces of number 1 , number 2, number 3, and number 4 rock bolts were 49.5, 84.8, 77.1 , and $30.8 \mathrm{kN}$, respectively.

\section{Discussion}

The application of FBG-based instrumented rock bolts avoided problems of electromagnetic interference in operations of electronic sensing technologies. As the developments on excavation technologies, there are increasing amounts of 


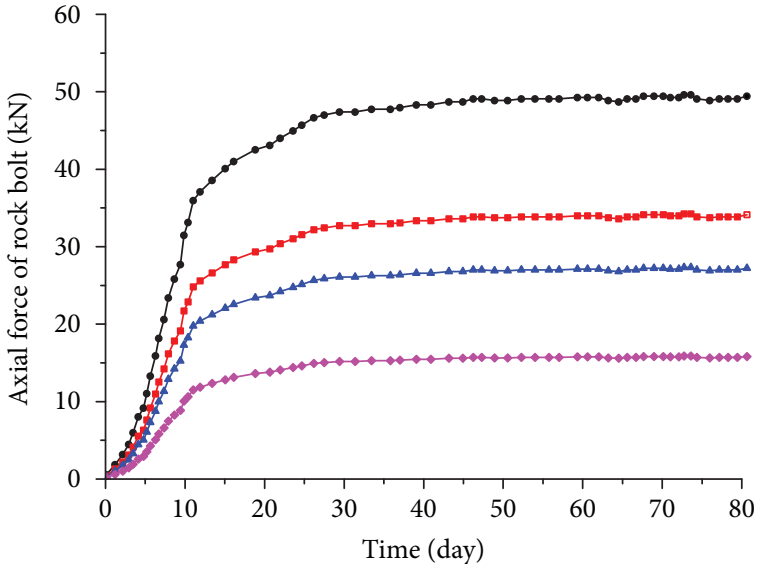

Distance to roadway surface

$$
\begin{array}{ll}
\rightarrow-0.1 \mathrm{~m} & \rightarrow-0.8 \mathrm{~m} \\
\rightarrow-1.5 \mathrm{~m} & \rightarrow-2.2 \mathrm{~m}
\end{array}
$$

(a)

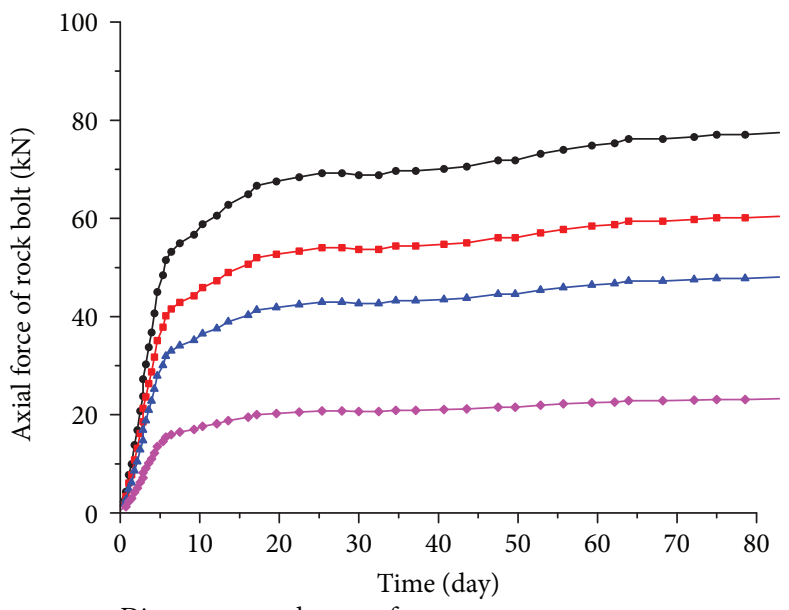

Distance to roadway surface

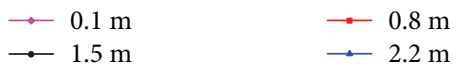

(c)

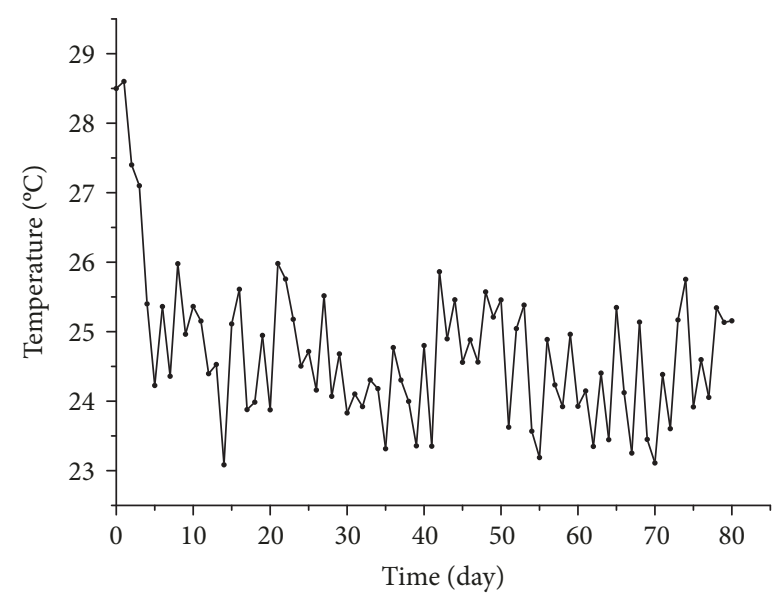

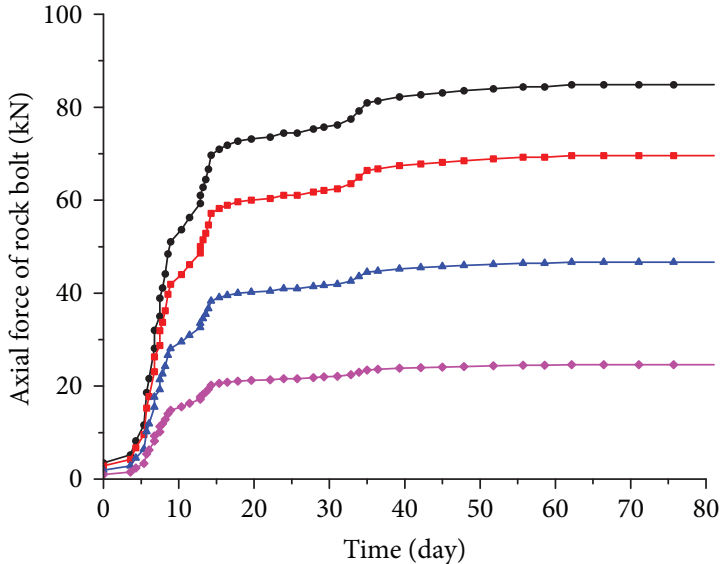

Distance to roadway surface

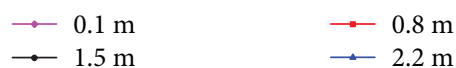

(b)

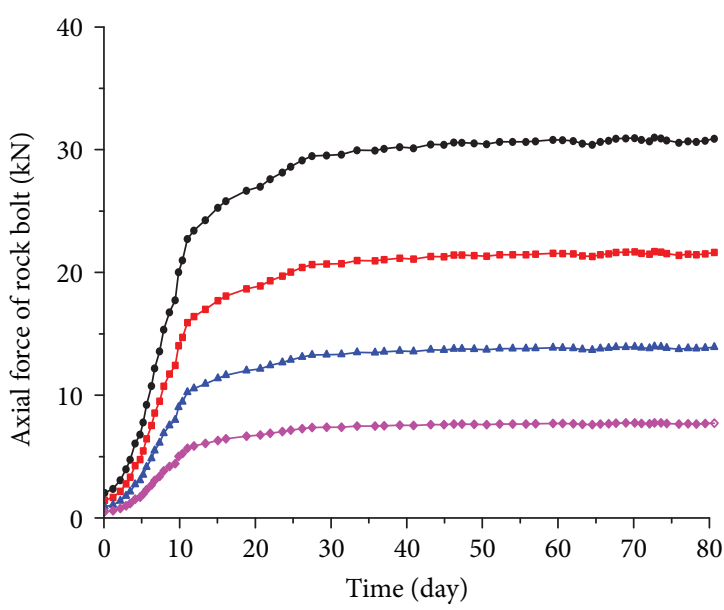

Distance to roadway surface

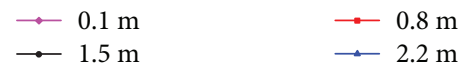

(d)

(e)

FIgURE 8: Monitoring results of axial forces and temperature of rock bolts: (a) monitoring results of number 1 rock bolt; (b) monitoring results of number 2 rock bolt; (c) monitoring results of number 3 rock bolt; (d) monitoring results of number 4 rock bolt; (e) measured temperature changes. 
high-powered equipment (such as TBM) applied in underground working sites. Consequently, conventional electronic sensors have increasing difficulty obtaining precise monitoring data under this circumstance.

Slotting the rock bolt and embedding FBG sensors which are encapsulated by epoxy resin, as well as installing instrumented rock bolts within boreholes, are capable of protecting FBG sensors from damage and external disturbance. The quasi-distributed layout of FBG sensors enables the instrumented rock bolts to monitor axial force along the alignment of rock bolts. The maximum axial force was measured on the middle portion rather than the rear part of the rock bolt; therefore, more data can be obtained by using the instrumented rock bolt than using conventional load cells which were installed on the rear of rock bolts.

The installation of the instrumented rock bolt is convenient. The installation procedure is the same as that of the normal rock bolt. Consequently, miners can install instrumented rock bolts without extra training. The instrumented rock bolts and normal rock bolts share the same material and similar mechanical structure; thus, the monitoring results are able to directly reflect the stress distribution behaviors of rock bolts. In addition, the instrumented rock bolts have capability of providing roadway support, and thus, installation of instrumented rock bolts will not reduce support strength of the roadway.

\section{Conclusions}

A FBG-based instrumented rock bolt had been proposed and successfully applied in Zhangji Coal Mine, China. An accurate, reliable, antielectromagnetic, and real-time monitoring of axial force of a rock bolt had been obtained by means of embedding FBG optical sensors in slotted rock bolts. The evolution of axial force distribution on rock bolts had been learned, and an early warning of rock bolt failure can be provided once the axial forces of rock bolts exceed the limits. In this study, only four FBG sensors were installed on each instrumented rock bolt, and four rock bolts were used. In future studies, more instrumented rocks can be installed, and, resting on them, an instrumented rock bolt array over wide extension of the roadway can be established and more detailed data of rock bolts are able to be obtained.

\section{Data Availability}

The data used to support the findings of this study are available from the corresponding author upon request.

\section{Conflicts of Interest}

The authors declare no conflict of interest.

\section{Acknowledgments}

The work presented in this paper is financially supported by the National Natural Science Foundation of China (Grant nos. 51804006, 51674006 and 51474004), National Science and Technology Major Project of China (Grant no. 2016ZX05068-001), Anhui Provincial College of Natural Science Research Key Project (Grant no. KJ2018A0098), and Youth Science Research Foundation of Anhui University of Science and Technology (Grant nos. QN2017211 and QN2017222). The authors gratefully acknowledge financial support of the above-mentioned agencies.

\section{References}

[1] R. Yang, Y. Li, D. Guo, L. Yao, T. Yang, and T. Li, "Failure mechanism and control technology of water-immersed roadway in high-stress and soft rock in a deep mine," International Journal of Mining Science and Technology, vol. 27, no. 2, pp. 245-252, 2017.

[2] X. R. Meng, R. Peng, G. M. Zhao, and Y. M. Li, "Roadway engineering mechanical properties and roadway structural instability mechanisms in deep wells," KSCE Journal of Civil Engineering, vol. 22, no. 5, pp. 1954-1966, 2018.

[3] W. Xue, Z. Yao, H. Cheng, and C. Rong, "Blasting vibration on deep shaft ingate rock damage and its control measures," Journal of Vibroengineering, vol. 18, no. 3, pp. 1639-1653, 2016.

[4] B. Tang, H. Cheng, Y. Tang et al., "Excavation damaged zone depths prediction for TBM-excavated roadways in deep collieries," Environmental Earth Sciences, vol. 77, no. 5, p. 165, 2018.

[5] H. Zhang, L. Wang, F. Gao, and H. Yang, "Numerical simulation study on the influence of the ground stress field on the stability of roadways," Mining Science and Technology, vol. 20, no. 5, pp. 707-711, 2010.

[6] Y. Kang, Q. Liu, H. Xi, and G. Gong, "Improved compound support system for coal mine tunnels in densely faulted zones: a case study of China's Huainan coal field," Engineering Geology, vol. 240, pp. 10-20, 2018.

[7] P. Gong, Z. Ma, R. R. Zhang, X. Ni, F. Liu, and Z. Huang, "Surrounding rock deformation mechanism and control technology for gob-side entry retaining with fully mechanized gangue backfilling mining: a case study," Shock and Vibration, vol. 2017, Article ID 6085941, 15 pages, 2017.

[8] G. Song, W. Li, B. Wang, and S. Ho, "A review of rock bolt monitoring using smart sensors," Sensors, vol. 17, no. 4, p. 776, 2017.

[9] R. Moffat, J. Sotomayor, and J. F. Beltrán, "Estimating tunnel wall displacements using a simple sensor based on a Brillouin optical time domain reflectometer apparatus," International Journal of Rock Mechanics and Mining Sciences, vol. 75, pp. 233-243, 2015.

[10] L. Ren, T. Feng, M. Ho, T. Jiang, and G. Song, "A smart "shear sensing” bolt based on FBG sensors," Measurement, vol. 122, pp. 240-246, 2018.

[11] M. A. Ibrar Jahan, R. V. Honnungar, and R. Versha, “Analysis of FBG sensor for accurate pressure sensing with improved sensitivity," Materials Today: Proceedings, vol. 5, no. 2, pp. 5452-5458, 2018.

[12] S. C. M. Ho, W. Li, B. Wang, and G. Song, "A load measuring anchor plate for rock bolt using fiber optic sensor," Smart Materials and Structures, vol. 26, no. 5, article 057003, 2017.

[13] M. Liang and X. Fang, "Application of fiber Bragg grating sensing technology for bolt force status monitoring in roadways," Applied Sciences, vol. 8, no. 1, p. 107, 2018. 
[14] Y. Zhao, Z.-Q. Li, and Y. Dong, "Design and experiments on a wide range fiber Bragg grating sensor for health monitoring of coal mines," Optik - International Journal for Light and Electron Optics, vol. 125, no. 20, pp. 6287-6290, 2014.

[15] P. M. Nellen, A. Frank, R. Broennimann, and U. J. Sennhauser, "Optical fiber Bragg gratings for tunnel surveillance," in Proceedings of SPIE - The International Society for Optical Engineering, vol. 3986, pp. 263-271, Newport Beach, CA, USA, 2000.

[16] M. Huang, Z. Zhou, Y. Huang, and J. Ou, "A distributed selfsensing FRP anchor rod with built-in optical fiber sensor," Measurement, vol. 46, no. 4, pp. 1363-1370, 2013.

[17] B. Benmokrane, M. Robert, H. M. Mohamed, A. H. Ali, and P. Cousin, "Durability assessment of glass FRP solid and hollow bars (rock bolts) for application in ground control of Jurong rock caverns in Singapore," Journal of Composites for Construction, vol. 21, no. 3, article 06016002, 2017.

[18] M. Salcher and R. Bertuzzi, "Results of pull tests of rock bolts and cable bolts in Sydney sandstone and shale," Tunnelling and Underground Space Technology, vol. 74, pp. 60-70, 2018.

[19] X. W. Ye, Y. H. Su, and J. P. Han, "Structural health monitoring of civil infrastructure using optical fiber sensing technology: a comprehensive review," The Scientific World Journal, vol. 2014, Article ID 652329, 11 pages, 2014.

[20] B. Torres, I. Payá-Zaforteza, P. A. Calderón, and J. M. Adam, "Analysis of the strain transfer in a new FBG sensor for structural health monitoring," Engineering Structures, vol. 33, no. 2, pp. 539-548, 2011.

[21] M. Majumder, T. K. Gangopadhyay, A. K. Chakraborty, K. Dasgupta, and D. K. Bhattacharya, "Fibre Bragg gratings in structural health monitoring-present status and applications," Sensors and Actuators A: Physical, vol. 147, no. 1, pp. 150-164, 2008.

[22] H. Kang, J. Yang, and X. Meng, "Tests and analysis of mechanical behaviours of rock bolt components for China's coal mine roadways," Journal of Rock Mechanics and Geotechnical Engineering, vol. 7, no. 1, pp. 14-26, 2015.

[23] B. Tang and H. Cheng, "Application of distributed optical fiber sensing technology in surrounding rock deformation control of TBM-excavated coal mine roadway," Journal of Sensors, vol. 2018, Article ID 8010746, 10 pages, 2018.

[24] C. Jia-sheng and G. Ming-zhong, "Research on integration of roadway excavation, bolting, support, and detection," Procedia Engineering, vol. 26, pp. 869-875, 2011.

[25] X. Huang, Q. Liu, K. Shi, Y. Pan, and J. Liu, “Application and prospect of hard rock TBM for deep roadway construction in coal mines," Tunnelling and Underground Space Technology, vol. 73, pp. 105-126, 2018.

[26] Y. Zheng, Q. B. Zhang, and J. Zhao, "Challenges and opportunities of using tunnel boring machines in mining," Tunnelling and Underground Space Technology, vol. 57, pp. 287-299, 2016.

[27] Q. Liu, X. Huang, Q. Gong, L. Du, Y. Pan, and J. Liu, “Application and development of hard rock TBM and its prospect in China," Tunnelling and Underground Space Technology, vol. 57, pp. 33-46, 2016.

[28] A. Hall, J. A. Scott, and H. Shang, "Geothermal energy recovery from underground mines," Renewable and Sustainable Energy Reviews, vol. 15, no. 2, pp. 916-924, 2011. 


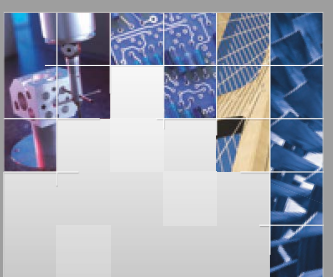

\section{Enfincering}
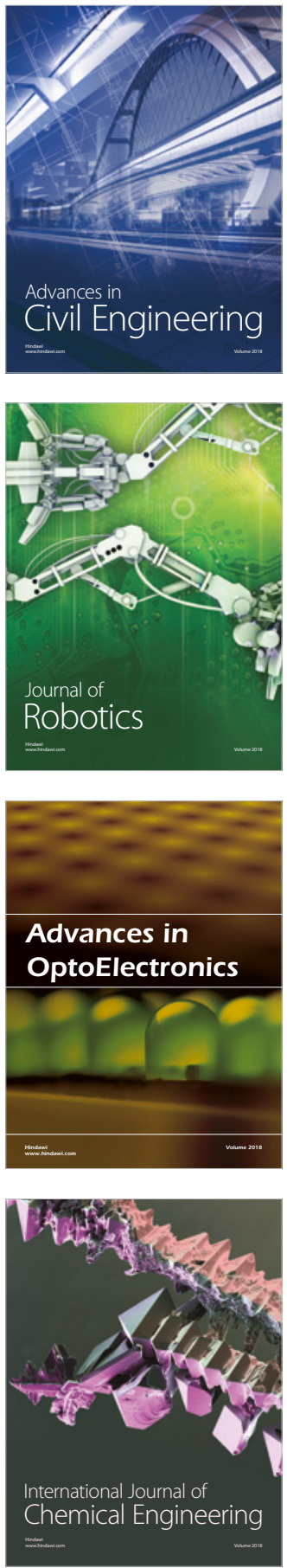

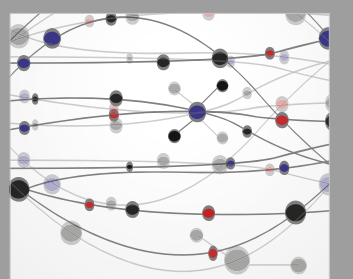

\section{Rotating \\ Machinery}

The Scientific World Journal

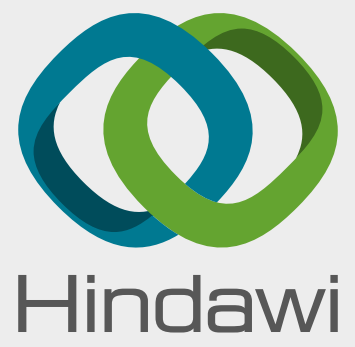

Submit your manuscripts at

www.hindawi.com
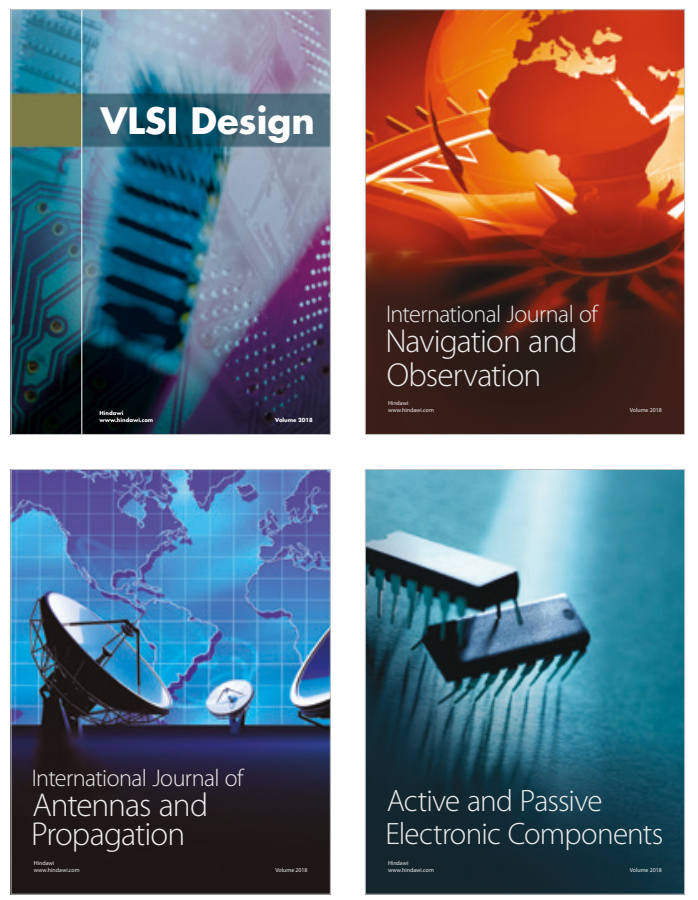
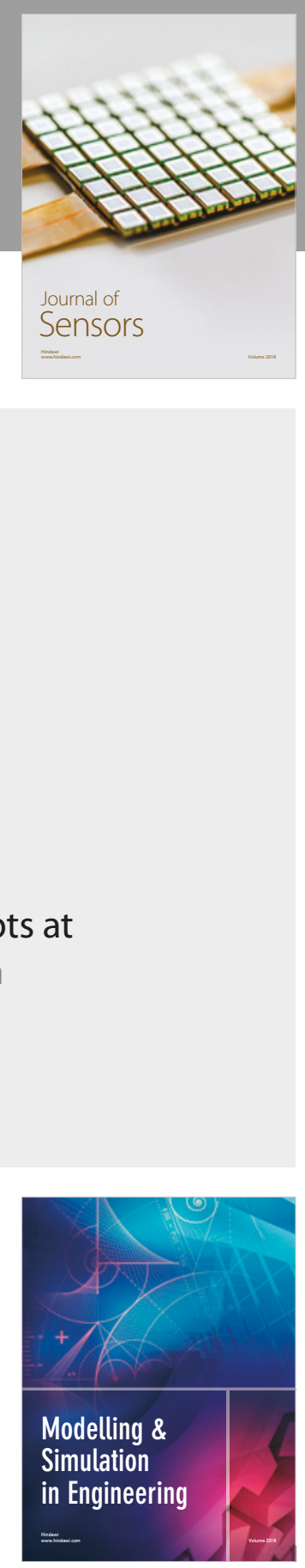

\section{Advances \\ Multimedia}
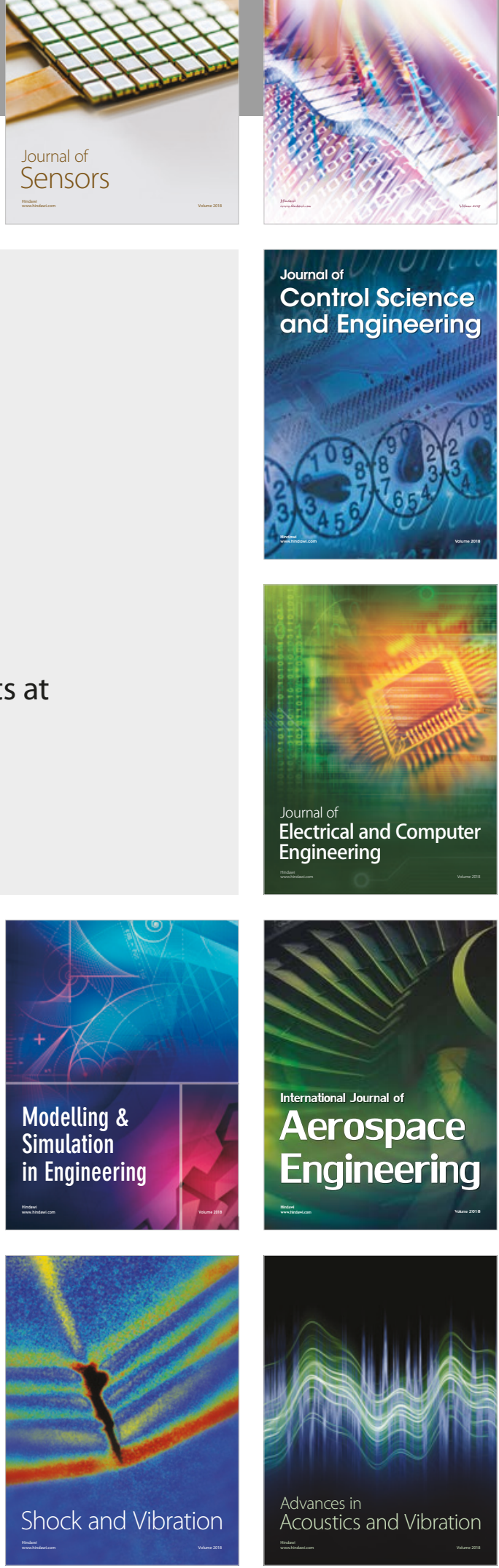